\title{
Social Intelligence of Principals and Its Relationship with Creative Behavior
}

\author{
Hani Kriemeen ${ }^{1, *}$ \& Sulaiman Hajaia ${ }^{1}$ \\ ${ }^{1}$ Department t of educational psychology, Faculty of Educational Sciences, Tafila Technical University, 66110 Tafila, \\ Jordan \\ *Correspondence: Department $\mathrm{t}$ of educational psychology, Faculty of Educational Sciences, Tafila Technical \\ University, P.O. Box 179, Tafila 66110, Jordan. Tel: 962-772-380-830. E-mail: hanikremen@yahoo.com
}

Received: May 4, 2017

doi:10.5430/wje.v7n3p84
Accepted: May 22, $2017 \quad$ Online Published: June 14, 2017

URL: https://doi.org/10.5430/wje.v7n3p84

\begin{abstract}
The study aimed at investigating the level of the social intelligence among the male and female principals in Tafila Governorate from the teachers views and its relationship with creative behavior.

The sample consisted of 190 male and female teachers chosen randomly. For achieving the goals of the study, the researchers developed two instruments, the first one was for social intelligence including 29 items, and the second one was for creative behavior including 22 items distributed on five domains: flexibility, originality, fluency, sensitivity to problems, and risk acceptance.

The results indicated that the level of social intelligence of principals was mid, and for creative behavior as well. The results also showed that there is a statistically significance positive correlative relationship between social intelligence and creative behavior.
\end{abstract}

Keywords: social intelligence; creative behavior; principal; school; teacher

\section{Introduction and Literature Review}

The positive interaction of a person with others leads to a pivotal role in his success or failure in occupational and social life, since he lives in an interlocked environment of relation, and the social intelligent behavior is characterized with its interest in people, practicing accepted behavior from society, and retaining with good relationships with others, so the success of an individual does not depend on cognitive intelligence but on social intelligence. The indicators of the social intelligence appear through the ability of the individual in understanding the others, the appropriate response with those of different motives, developing friend ships, the ability in interaction with others, and behaving wisely with them, the success of the individual in life basically depends on the degree of perception and understanding the multi variables towards the problems that the individual faces in his life (Al-khaldi 2009).

The research in social intelligence started by Thorndike when he presented a triple classification with three dimensions for intelligence: social intelligence, mechanic intelligence, and abstract intelligence; the mechanic intelligence indicates the skill of dealing with materials, instruments, and devices, whereas, the abstract intelligence deals with theoretical behavior and the ability in dealing with symbols, verbs, and forms, and the social intelligence points out to the intelligent interaction with others (Unterborn, 2011). Some scientists defined the social intelligence concept in different definitions as, Gardner defined it as the ability of perception and the response to others moods, wishes, and their latent feelings and abilities. Jones \& Day 1997 defined the social intelligence as the ability in employing cognition for social problems solution. Other scientists gave precise details about the social intelligence concept and pointed out to three systems as:

1- Social control, which concentrates on social roles with accurate and well organized way and high proficiency

2- Social expression, which presents accurate description, and ideas translation into sensitive sentences and meanings

3- Social sensitivity, which shows persons daily interaction with events (Goleman-2006). The educational literature points out to the importance of social intelligence in different occupations success, such as, teaching career which requires good interaction between the teacher and his students, in addition to high ability in 
understanding others, communication, interaction, flexibility, on high proficiency based on the philosophy that the social intelligence affects positively in cognitive performance, thinking processes, behavior that is reflected on students achievement, their abilities in performance innovation class activity, and construction of cooperative system where all the elements of teaching process participate with (Cherniss, 2000). The social intelligence is connected with psychological health which is reflected positively on understanding the others, effective communication, precise perception of their emotions, agreement to problem solution, and finding a situation of coherence between individual and social environment (Esthood, 1995).

According to social intelligence theories; intelligence is associated with the cognitive component and other components, these components facilitate social communication. According to Goleman (2006) theory; social intelligence has two dimensions: cognitive and emotional. The concept of social intelligence refer to the ability to understand thoughts, feelings and behaviors of the others in different social situations, it also consisted of the skills which enable individuals to solve social problems (Abuhashim, 2008). Principals creative behavior form a transition point to utilize resources, improve work strategies, solve problems, and establish school environment that is able to observe the weakness, changes, limiting reasons, and comprehend results which appears deep understanding to the educational work philosophy. The creative solutions are more flexible and fluent in data collection and limiting problems and substitute development and examining thoughts (Balwahi, 2008).

The creative Principals were characterized by the ability to adapt with changes realistic thinking, and their ability to establish thinking model based upon imagination, construction synthesis, analysis, organization and evaluation, they also should have the ability to accept changes, cope with crises, committed to perform work and accept others opinion.

Many studies were conducted to investigate the role of social intelligence and creative behavior in school management. Gasim (2012) Conducted a study that aimed to know the social intelligence level among secondary school principals in Kuwait and its effect upon organizational stress. The results showed that the level of social intelligence among principals was high, the organizational stress was mid and there were statistically significant differences in organizational stress attributed to social intelligence. The study of Yahyazadeh and Goodarzi (2012) aimed to investigate the relationship between social intelligence and personal traits of secondary school principals in Iran, the sample consisted of 198 teachers. The results of the study were: there is statistical significant differences in social intelligence level and personal traits of the teachers attributed to their age, and a positive correlation between social intelligence and personal traits. The study of Jeloudar and Yunis (2011) used 203 teachers from governmental school in Malaysia to find the level of social intelligence among teachers and its relationship with some strategies for classroom control. The results indicated that: the level of social intelligence increases with age and a positive correlation between classroom control strategies and social intelligence. kasim (2009) found that the level of social intelligence among the students of education college at Mustansiriah University was high, and their ability to take decision was also high. Alkhazraji and Azi (2010) found that social intelligence level among students of Dialy college was high and there was a positive correlation between social intelligence and students achievement. The study of kasim (2009) aimed to investigate the relationship between social intelligence and solving problems among Bagdad university students, the sample of the study consisted of 400 students, the study indicated positive correlation between social intelligence and problem solving, and there were no significant differences in social intelligence attributed to sex, academic field and academic level. Askool (2009) conducted a study which aimed to find the relationship between social intelligence, critical thinking and some variables, the sample of the study consisted of 381 students, they were randomly chosen from Islamic university students. The results of the study showed that the social intelligence level was low, the critical thinking level was mid and there was a statistically significant correlation between social intelligence and critical thinking. The study of Bilwani (2008) indicated that $70.4 \%$ of the principals in Palestine agreed that school principals play a great role in developing creative behavior. The study of Toremen (2003) determined the factors that enhance creative behavior at schools: fairness evaluation, encourage teachers to work without fear, support teachers, and provide them with creative organizational atmosphere.

\section{Statement of the Problem}

Social intelligence is considered to be one of the most important elements in school management. It enables principals to develop their work and solve problems. The effective school management implement social intelligence in meeting with teachers, seminars, evaluation of the school work, and communications. The study of Alkaied (2008) found that school principals were still use linear method of thinking in spite of many workshops and training provided by Ministry of Education for principals to use different types of thinking. 
According to that the study aimed to answer the following questions

1- What is the social intelligence level of the school principals at Tafila Directorate of Education from teachers point of views?

2- What is the creative behavior level among school principals at Tafila Directorate of Education from teachers point of views.

3- Is there a statistical significant relationship between social intelligence and creative management?

\section{Procedural Definitions}

social intelligence: the ability of the individual to interact, communicate and establish mutual relations with the others it consisted of three components:

social awareness, social skills and information management (Silvera, Martinussen and Dahl,2001). In this study social intelligence is: the ability of principals to establish positive relations inside and outside the school which will be measured by using the social intelligence scale.

Creative management: the degree that the principals will have according to the creative behaviors scale from teachers' point of views.

\section{Methodology}

\subsection{Design}

The study adopted the descriptive design because it is the suitable method for this study.

\subsection{Population}

The population of the study consisted of teachers 1833 at Tafila Directorate of Education.

\subsection{Sample}

The study sample consisted of 190 teachers (10.3\%) they were chosen randomly.

\subsection{Instrument}

To achieve the objectives of the study the related literature was reviewed (Tamimi and Thabet, 2010, Juloder and Younes, 2011, Gasim, 2012, Abuamsha 2013, Kasim 2209). According to that the instruments were developed as follows:

1 - social intelligence scale (29 items)

2- administrative creativity scale: it consisted of 22 items, and 4 domains: originality ( 5 items), fluency (4 items), flexibility (4 items), sensitivity to problems (4 items), and risk acceptance (5 items). The respondents were asked to respond to the items using Likert scale (5 strongly agree, 4 agree, 3 neutral, 2 disagree, 1 strongly disagree).

\subsection{Validity}

Validity of the 2 instruments was approved through experts judgments, 8 experts in educational management, measurement and evaluation, and general management. They were asked to review the 2 instruments, and according to their notes the instruments were modified

\subsection{Reliability}

Reliability was checked using internal consistency (Cronbach $\alpha$ equation) table 1 represents the findings

Table 1. Reliability of the Instruments

\begin{tabular}{lcc}
\hline \multicolumn{1}{c}{ Instrument } & Domain & Reliability \\
\hline Social intelligence scale & & 0.97 \\
Social intelligence scale & Originality & 0.87 \\
& fluency & 0.83 \\
& flexibility & 0.85 \\
& Sensitivity to problems & 0.77 \\
Administrative creativity scale & Risk acceptance & 0.80 \\
& & 0.96 \\
\hline
\end{tabular}


According to table 1, the figures for reliability were accepted for the study purposes

\subsection{Statistical Analysis}

SPSS was used to analyze the data, the following statistics were used:

Pearson correlation coefficient, means and standard deviations; the following criteria were used to make judgments about the means: 1-2.33 (Low). 2.34-3.67 (mid) and 3.68-5 (high).

\section{Results}

\subsection{Question 1}

To answer question 1 (what is the social intelligence level of the school principals at Tafila Directorate of Education from teachers point of views?) means and standard deviations for the items of social intelligence scale were calculated, table 2 represent the findings.

Table 2. Means and Standard Deviations for Social Intelligence Scale

\begin{tabular}{|c|c|c|c|c|}
\hline Item no. & Item & mean & SD & Rank \\
\hline 5 & Principal can interact easily with teachers. & 4.25 & 0.91 & high \\
\hline 20 & Principal has the ability to affect teachers positively & 4.23 & 0.87 & high \\
\hline 3 & Principal can understand nonverbal communication of the teacher & 4.16 & 0.91 & high \\
\hline 19 & Principal has the ability to affect teachers objectives & 3.68 & 0.89 & high \\
\hline 1 & Principal has high social stability. & 3.62 & 0.87 & \\
\hline 6 & Principal has self confidence in accomplishing school duties & 3.58 & 0.88 & mid \\
\hline 11 & Principal can interact with teachers without fear. & 3.46 & 0.99 & mid \\
\hline 8 & Principal realizes teachers opinions. & 3.45 & 0.90 & mid \\
\hline 14 & Principal has the ability to convince teachers with his point of view. & 3.44 & 0.87 & mid \\
\hline 10 & Principal provides positive climate in the work. & 3.24 & 0.92 & mid \\
\hline 7 & Principal encourages teachers. & 3.22 & 0.88 & mid \\
\hline 16 & Principal enjoys working with teachers. & 3.22 & 0.87 & mid \\
\hline 13 & Principal has a lovely personality among teachers. & 3.2 & 0.80 & Mid \\
\hline 9 & Principal participates in social activities at school. & 3.2 & 0.89 & mid \\
\hline 15 & Principal take cares of social issues inside and outside school. & 3.2 & 0.91 & mid \\
\hline 12 & Principal provides teachers with friendly relations. & 3.18 & 0.95 & mid \\
\hline 17 & Principal displays optimism and joy with teachers. & 3.18 & 0.96 & mid \\
\hline 23 & Principal provides teachers with different methods to solve school problems. & 3.17 & 0.93 & mid \\
\hline 4 & Principal behaves professionally when he is exposed to work stress. & 3.14 & 0.96 & mid \\
\hline 2 & Principal acts with transparency and rationality with teachers. & 3.11 & 0.93 & mid \\
\hline 27 & Principal accepts criticism. & 3.11 & 0.87 & mid \\
\hline 22 & Principal attracts teachers attention during his speech with them. & 2.90 & 0.95 & mid \\
\hline 18 & Principal has good charisma during school meetings. & 2.89 & 0.88 & mid \\
\hline 24 & Principal has good experience. & 2.88 & 0.91 & mid \\
\hline 29 & Principal accepts teachers point of views. & 2.69 & 0.87 & mid \\
\hline 26 & Principal inspires teachers through his work in the school. & 2.55 & 0.94 & mid \\
\hline 21 & Principal has the awareness of group work in the school. & 2.50 & 0.90 & mid \\
\hline 28 & Principal makes friendly relations with teachers. & 2.45 & 0.99 & mid \\
\hline 25 & Principal has the aptitude to solve teachers problems. & 2.15 & 0.77 & low \\
\hline \multicolumn{2}{|r|}{ Total } & 3.20 & 0.77 & mid \\
\hline
\end{tabular}


Table 2 shows that the social mean is mid (3.20): items 5 (Principal can interact easily with teachers) has the highest mean (4.25), also the items 3.19 and 20 have high means, item 25 Principal has the aptitude to help teachers insolving their problems) has low mean (mean $=2.15, \mathrm{SD}=0.93$ ), while all other items have mid mean.

The result could be explained by the fact that social intelligence is correlated with different skills, interaction with others, communication and the ability to understand with others and these need distinguished organization and high level of abilities. The explanation for high mean of item 5 could be due to the fact that management needs good interaction to perform tasks; while the low mean for item 25 could be due to the variety of technical and administrative tasks. The results differ from Gasim (2012) and Tamimi (2010) results and similar to Askool (2009) results.

\subsection{Question2}

To answer question 2 (What is the creative behavior level among school principals at Tafila Directorate of Education from teachers point of views), means and standard deviations for creative behavior were computed. Table 2 represent the findings.

Table 2. Means and Standard Deviations for Creative Behavior Scale

\begin{tabular}{lccc}
\hline \multicolumn{1}{c}{ Domain } & Mean & SD & Rank \\
\hline Originality & 3.07 & 0.70 & $\mathrm{mid}$ \\
fluency & 2.86 & 0.72 & $\mathrm{mid}$ \\
flexibility & 3.36 & 0.77 & $\mathrm{mid}$ \\
Sensitivity to problems & 3.56 & 0.75 & $\mathrm{mid}$ \\
Risk acceptance & 3.35 & 0.74 & $\mathrm{mid}$ \\
\hline
\end{tabular}

Table 2 shows that creative behavior scale has mid rank mean (3.24); sensitivity to problems domain was the highest (mean-3.56 SD =0.75), while fluency domain was the lowest mean (mean=2.86 SD $=0.72$ ) this result could be due to have technical and administrative of tasks rely on principals, lack of training programs, low support to schools from ministry of education, and the bureaucracy of decision making. The results of this question is similar to Ayoub, (2008) and differ from Balwani(2008) results.

The means and standard deviations were calculated for the items of creative behavior scale. Table 3 represents the means and standard deviations for authenticity domain.

Table 3. Means and Standard Deviations for Authenticity Items

\begin{tabular}{clccc}
\hline Item No & Item & means & SD & Rank \\
\hline 4 & Principal perform school works using innovative methods & 3.55 & 0.83 & mid \\
2 & Principal doesn't imitate others in solving problems. & 3.45 & 0.78 & mid \\
5 & Principal avoids repetition to perform school work & 3.14 & 0.76 & mid \\
1 & Principal has good communication skills to convince others. & 3.14 & 0.96 & mid \\
3 & Principal generates new ideas for school work. & 2.11 & 0.81 & low \\
& Total & 3.07 & 0.93 & mid \\
\hline
\end{tabular}

Table 3 indicates that all items of authenticity domain were mid except item 3 with low mean (principal involved in producing new ideas for school work).

Item 4 (principal accomplish school work using new methods) has the highest mean (3.55). the results in general for authenticity indicated that principal s had mid means for most aspects of authenticity, this could be due to the fear of fail, principal s resists changing the way they solve problems to avoid criticism, this result is similar to (Toremen,2003). For the second domain (Fluency) means and standard deviations were calculated as table 4 represents. 
Table 4. Means and Standard Deviations for Fluency Domain

\begin{tabular}{|c|c|c|c|c|}
\hline Item No & item & means & SD & Rank \\
\hline 6 & Principal suggests quick methods to solve school problems. & 3.22 & 0.90 & mid \\
\hline 8 & Principal suggests different ideas in short time. & 2.99 & 0.80 & mid \\
\hline 9 & Principal has the ability to generate synonyms for the same ideas. & 2.69 & 0.84 & mid \\
\hline \multirow[t]{2}{*}{7} & Principal has the ability to think fast for school situations. & 2.55 & 0.84 & mid \\
\hline & Total & 2.86 & 0.91 & mid \\
\hline
\end{tabular}

Table 4 showed that all the items for fluency domain were mid mean (2.86). Item (6) had the highest mean, while item (7) had the lowest. The results for this domain were similar to the findings of Balwani (2008).

The third domain flexibility means and standard deviations for this domain were calculated. Table 5 represents the results.

Table 5. Means and Standard Deviations for Flexibility Domain

\begin{tabular}{|c|c|c|c|c|}
\hline $\begin{array}{l}\text { Item } \\
\text { No. }\end{array}$ & item & means & $\begin{array}{c}\text { standard } \\
\text { deviations }\end{array}$ & Rank \\
\hline 11 & Principal introduces new ideas to develop. & 3.66 & 0.86 & mid \\
\hline 13 & Principal insists to change his ways of doing jobs. & 3.55 & 0.83 & mid \\
\hline 12 & Principal has the ability to realize issues from different directions. & 3.14 & 0.91 & mid \\
\hline \multirow[t]{2}{*}{10} & Principal changes his opinion if he/she realized that he /she is wrong. & 3.11 & 0.87 & mid \\
\hline & Total & 3.36 & 0.92 & mid \\
\hline
\end{tabular}

Table 5 showed that mental flexibility domain was mid (3.36), item 11 had the highest mean, this could be due to the continuous needs of ideas to develop school. Item 10 had the lowest mean; principal s sometimes need to insist on their ideas to achieve the school goals and some principals may resist changes or accept the new ideas.

The $4^{\text {th }}$ domain was sensitivity to problems, table 6 represents the means and standard deviations for sensitivity to problems domain items.

Table 6. Means and Standard Deviations for Sensitivity to Problems Domain

\begin{tabular}{clccc}
\hline Item no & \multicolumn{1}{c}{ item } & means & standard deviations & Rank \\
\hline 15 & Principal can predict school problems before it occurred & 3.89 & 0.88 & high \\
17 & Principal can plan to solve problems before it occurred & 3.49 & 0.82 & mid \\
14 & Principal insists to know strength and weak nesses in his work & 3.44 & 0.93 & mid \\
16 & Principal discovers teachers problems and help them to solve it & .343 & 0.85 & mid \\
& Total & 3.56 & 0.90 & mid \\
\hline
\end{tabular}

Table 6 showed that the mean for sensitivity to problems domain items was mid (3.56). Item 15 had the highest mean, while item 16 had the lowest. The mid mean for most of the items could be due to the using of traditional and logical methods in solving problems instead of using the scientific way to solve problems, and most of the principals thought that there was one method to solve the problem, the findings of the study is countered the findings of khazraji (2010) and Tamimi (2010), while they are similar to the findings of Jeloudar and Yuns (2010). The 5th domain: risk acceptance. Table 7 represents the risk acceptance items means and standard deviations. 
Table 7. Means and Standard Deviations for Risk Resistance Domain

\begin{tabular}{|c|c|c|c|c|}
\hline Item no. & item & means & $\begin{array}{c}\text { standard } \\
\text { deviations }\end{array}$ & Rank \\
\hline 20 & Principal accepts teachers criticism friendly. & 3.56 & 0.88 & mid \\
\hline 22 & Principal accepts failure and considered it as a way for success. & 3.48 & 0.93 & mid \\
\hline 18 & Principal has the ability to defend his ideas. & 3.44 & 0.89 & mid \\
\hline 21 & Principal adopts recent ideas and methods to solve school problems. & 3.19 & 0.90 & mid \\
\hline \multirow[t]{2}{*}{19} & Principal takes the responsibility of the school works. & 3.11 & 0.92 & mid \\
\hline & Total & 3.35 & 0.94 & mid \\
\hline
\end{tabular}

Table 7 showed that all items of risk acceptance were mid, item 20 had the highest mean while, item 19 had the lowest, usually principals afraid of failure so they avoid risk because risk acceptance needs unusual ideas and high ability to cope with crises and to think in success more than failure.

\subsection{Question3}

To answer question 3 (Is there a statistical significant relationship between social intelligence and creative management?) Pearson correlation coefficient was used. Table 8 shows the results.

Table 8. Pearson Correlation between Social Intelligence and Creative Behavior Domains

\begin{tabular}{ccccccc}
\hline Creative behavior & authenticity & fluency & flexibility & Sensitivity to problems & Risk acceptance & scale \\
\hline Social intelligence & $0.664^{*}$ & $0.669^{*}$ & $0.667^{*}$ & $0.667^{*}$ & $0.685^{*}$ & $0.735^{*}$ \\
\hline$(\alpha=0.01)$ & & & & & &
\end{tabular}

Table 8 indicated that the correlation between social intelligence and creative behavior social and domains were positively correlated and this correlation is statistically significant $(\alpha=0.01)$. This result indicates the importance of social intelligence to create positive work climate to enhance different methods in communication exchange ideas, support ideas of change, accept risk and searching for various ways to solve problems, this result is similar to the findings of Yahazadeh and Goodarzi, 2012 and Jeloudar and Yuns, 2011.

\section{Conclusion}

The principal had mid level of social intelligence and creative behavior, the relationship between social intelligence and creative behavior is statistically significant positive relation.

\section{Recommendations}

According to the study results, the researchers recommend the following: train Principal s to implement social skills in school management, train Principal s to use creative thinking strategies, and develop management programs which depend up on social skills and creative thinking.

\section{References}

Abuamsha, B. (2013). Social intelligence and emotional intelligence and their relationship with happiness among Gaza University students. Master Thesis College of Education. Alazhar University. Gaza.

Abuhashim, M. (2008). The components of social, emotional intelligences and their relationship among Saudi and Egyptian University students, a comparative study. College of Education Journal, 18(76), 71-95.

Alkaied, R. (2008). The degree of social intelligence among secondary school principals in Jordan and its relationship with students regulations control and school-community interaction. PhD. dissertation. Amman Arab University. Jordan.

Alkhazraji, I., \& Azi, A. (2010). Social intelligence and its relationship with achievement among students of female teachers college. Dialy Journal, 47, 35-52.

Askool, K. (2009). Social intelligence and its relationship with critical thinking and some variables among University students. Master Thesis College of Education. Islamic University. Gaza. 
Balwani, N. (2008). The role of school management in developing creativity in governmental schools in northern region of Palestine and the obstacles from principals point of views. Master thesis. Alnajah University.

Cherniss, C. (2000). Emotional intelligence. What is it and why it matters paper presented at the annual meeting to the society for industrial an organizational psychology. New Orleans LA-www Eiconsortium.org.

Easthood, A. (1995). Psychology of adjustment personal growth world. Prentice hall: New York.

Gasim, G (2012). Social intelligence level among secondary schools principal in Kuwait and its relationship with organizational stress. Education journal, 7(5), 32-38.

Goleman, D. (2006). Social Intelligence. New York: Bantam Dell.

Jeloudar, S., \& Yunus, A. (2011). Exploring the Relationship between teachers Social Intelligence and Classroom Discipline Strategies. International Journal of Psychlogical Studies, 3(2), 149-155. https://doi.org/10.5539/ijps.v3n2p149

Jones, K., \& Day, J. (1997). Discrimination of two aspects of cognitive-social intelligence from academic intelligence. Journal of Educational Psychology, 89, 486-497. https://doi.org/10.1037/0022-0663.89.3.486

Kasim, I. (2009). Social intelligence and its relationship with problem solving among university students. Journal of psychological and educational research, 21, 66-91.

Khalidi, I. (2009). Social intelligence and its relationship with inside and outside locus control among Bagdad University. Master Thesis. Bagdad University Iraq.

Silvera, D., Martinussen, M., \& Dahal, T. (2001). The tromso social intelligence Scale, a self- report measure of social intelligence. Scandinavian Journal of Psychology, 42, 313-319. https://doi.org/10.1111/1467-9450.00242

Talalfha, H. (2014). Social intelligence level among social studies teachers at zarka province and its relationship with classroom interaction patterns. Dirasat, 41(2), 87-109.

Troman, F. (2003). Creative school and administration. Educational sciences: theory and practical, 3(1), 248-253.

Unterborn, K. (2011). Creating a performance-based social intelligence measure using situational judgment test format. Unpublished Dissertation. Central Michigan University, Mount Pleasant, Michigan, USA.

Wong, C., Day, J., Maxwell, S., \& Meara, N. (1995). A multi trait- multi method study of academic and social intelligence in college students. Journal of Educational Psychology, 87, 117-133. https://doi.org/10.1037/0022-0663.87.1.117

Yahyazadadeh, S., \& Goodarzi F. (2012). Predicting Senior Secondary Schools Teachers Social Intelligence by HEXACO-PI-R personality Traits based on Age Groups. International Journal of Asian Social Science, 2(5), $739-747$.

Yunis, M. (2000). Management success. Riyad: Alafkar Aldawleh Publishing. 